\title{
Population Status of Tapanuli Orangutan (Pongo tapanuliensis) within the Renewable Energy Development and its Management Implications
}

\author{
Didik Prasetyo ${ }^{1,}{ }^{*}$, Yokyok Hadiprakarsa ${ }^{2}$, Wanda Kuswanda ${ }^{3}$, and Jito Sugardjito ${ }^{4}$ \\ 1 Fakultas Biologi, Universitas Nasional, Jakarta, Indonesia. \\ 2 Independent Researcher, Bogor, Indonesia. \\ 3 Balai Penelitian Kehutanan Aek Nauli, Sumatera Utara, Indonesia. \\ 4 Center for Sustainable Energy and Resources Management (CSERM), Universitas Nasional, Jakarta, \\ Indonesia. \\ * Correspondence author: didik@primata.or.id; Tel.: +6281387060811
}

\begin{abstract}
To protect Tapanuli orangutan it is essential to understand the actual situation. It has been studied $15 \%$ of its population live outside the protected area facing a density disruption due to forest conversion. Several best management practices have been created and tested for different natural concession types. Yet, the main objective to reduce the impact and increase wildlife survival is far away from the goal. To improve our understanding of the species survival within ongoing project construction, we conducted population density monitoring prior- to post-construction time frames within the hydroelectric dam project. Also, we carried out spatial analysis to understand the land cover change and orangutan's suitable habitat distribution. This study found that during high construction activities, orangutans were avoiding the threat sources, and returned when the disturbances reduced. These findings indicated orangutans are ecology flexible and have the capability to increase its survival, although the company's involvement is crucial to facilitate the successes. Our study is based on indirect observation, and spatial modeling, which may lead to an uncertain conclusion. Further research on orangutan ecology and behavior is prioritized.
\end{abstract}

Keywords: Tapanuli; Orangutans; Hydroelectric dam; Batang Toru; Renewable energy

\section{Introduction}

Recently, the occurrence of newly described orangutan species, i.e., Pongo tapanuliensis or commonly known as Tapanuli orangutan has engaged the attention of several parties such as the Indonesian government, non-government organizations, and universities or researcher. Nater et al. (2017) described Tapanuli orangutan as taxonomically different from other Ponginae members, and this was based on their craniomandibular and dental characters, morphology, and DNA analyses. It did not wait long after it was published, The Indonesian Ministry of Forestry and Environmental has announced and stated it as protected species by law number P.106/MENLHK/SETJEN/KUM.1/12/2018. This decision supported the conservation status that released by the International Union for Conservation of Nature (IUCN) (Nowak et al., 2017).

The coincidental identification of a new species of orangutan, Tapanuli orangutan (Pongo tapanuliensis), in 2017 (Nater et al., 2017), within the same watershed as an approved site for a new run-of-river hydroelectric project in Batang Toru area of Northeast Sumatra, has resulted in considerable concern and conflict between specific conservation interests and those pursuing the development of renewable energy. Until the recent study on a specimen by Nater et al. (2017), the orangutan population in the project areas had for years been assumed to be the same species (Pongo abelii) found elsewhere in Sumatra. This relatively isolated the population of $P$. tapanuliensis to be approximately 800 individuals and they resided in several semi-connected forest blocks variously designated as "Protected Forest, Production Forest, Conservation Forest, and Other Use Forest". The primary forested blocks occupied by $P$. tapanuliensis are: Batang Toru protected forest and three nature reserved forests (Dolok Sipirok, Dolok Sibual-buali, and Lubuk Raya). While no collection of accurate trend data to date, some analysis suggested that the population is declining 
(Wich et al., 2008; Wich et al., 2012; Nater et al., 2017; Wich et al., 2019). Factors acknowledged to be contributing to this reduction are similar to those affecting orangutan throughout their range in Indonesia and Malaysia, namely land conversion for agriculture, settlement, and resource extraction (mining, legal and illegal logging); orangutan-human conflict; and poaching for the illegal wildlife trade and bushmeat (Utami-Atmoko et al., 2017; Wich et al., 2019). Current population trend estimates $P$. tapanuliensis suggest a potential 1.2\% decline over the next ten years (Utami-Atmoko et al., 2019). In recognition of the habitat needs for orangutan and several other species with special conservation status in Batang Toru, the government of Indonesia, through the Ministry of Forestry letter number 243/Menhut-II/2011, has set aside a 168,658 ha $\left(1,686 \mathrm{Km}^{2}\right)$ area in the north-eastern part of Batang Toru ecosystem as "Protection Forest". The current construction of the run-of-river Batang Toru Hydro Electric project on non-protected lands is designated as "Other Use" at the extreme South end of the largest of five forest blocks supporting P. tapanuliensis. The project's clearing and construction activities have removed an estimated 618 ha of vegetation cover (various forest cover types, plantations, and agricultural lands) representing approximately $1.2 \%$ of the 145,800 ha, conservatively estimated to be habitat occupied by $P$. tapanuliensis in the Batang Toru ecosystem.

Ongoing concerns over the impact of the Batang Toru Hydro Electric Project (HEP) for $P$. tapanuliensis, have focused on several issues, the main ones being: 1) That they developed the runoff river hydropower project in an area with the highest density of Tapanuli orangutan (Wich et al., 2012; Wich et al., 2019) 2) The project will flood $96 \mathrm{Km}^{2}$ of orangutan habitat (Sloan et al., 2018); 3) The project construction would negatively impact the habitat for several resident individuals (Wich et al., 2019); 4) The project would genetically isolate the small $P$. tapanuliensis sub-population found in the Sibual-buali reserve area from those in the much larger west block population; and 5) The establishment of the construction activities would facilitate human access to $P$. tapanuliensis habitat and bring with it increased risk of hunting, illegal logging, development of previously isolated private lands, and human-animal conflict. Based on those concerns, Wich et al. (2019) assumed that the Batang Toru hydropower project's establishment would accelerate the decline in $P$. tapanuliensis populations in the Sibual-buali and Sipirok reserve areas and, when combined with other risk factors, result in eventual species extinction.

This study provides new data on P. tapanuliensis in proximity to the Batang Toru hydropower project during and post-construction activities. Additionally, the study assessed the potential conservation outcome for this critically endangered species in light of the project proponent's ongoing and planned mitigation and any additional practical conservation measures that might be implemented. This study summarizes an intensive contemporary spatial analysis of orangutan density and habitat within 1,812 ha area centered on the Batang Toru HEP study area, juxtaposed with information on $P$. tapanuliensis sub-populations metapopulation.

\section{Materials and Methods}

\subsection{Study area}

The study was carried out in PT North Sumatera Hydro-Energy (NSHE), North Sumatera, Indonesia, with the total exploration permit per December 2019 is 1,812 hectares (Figure 1). Administratively, PT NSHE is located at the southwest of Toba Lake and the district of South Tapanuli, North Sumatera. We varied the elevation from 50-1875 meters above sea level with slopes characteristic from $16^{\circ}$ to $60^{\circ}$. According to the established reports, the project development was right after the Batang Toru River, which the forest categorized as a secondary forest type. As the status of the forest was for other purposes, Hevea brasiliensis (IVI=16.19) were dominated within the study area (Kuswanda \& Noor CH, 2017; Rahman et al., 2019).

Historically, Tapanuli orangutans were found from the upland of West Toba lake in North Sumatra to the Bukit Tinggi district, West Sumatra (Meijaard et al., 2021). The current population was found within the Batang Toru ecosystem, North Sumatera. Their distribution was divided into three different forest blocks i.e. the west block which about 581 orangutans live, the east block with an estimate of 162, and the Sibual-buali Reserve with 24 individuals (Wich et al., 2016; Wich et al., 2019) as well as Lubuk Raya Reserve which estimated less than 5 individuals (Prasetyo et al., 2021). Of this distribution, the Tapanuli orangutan population was dispersed mainly within the protected 
area $42,98 \%$ and $15,54 \%$ could be found in the non-protected area (Nowak et al., 2017; Rahman et al., 2019).

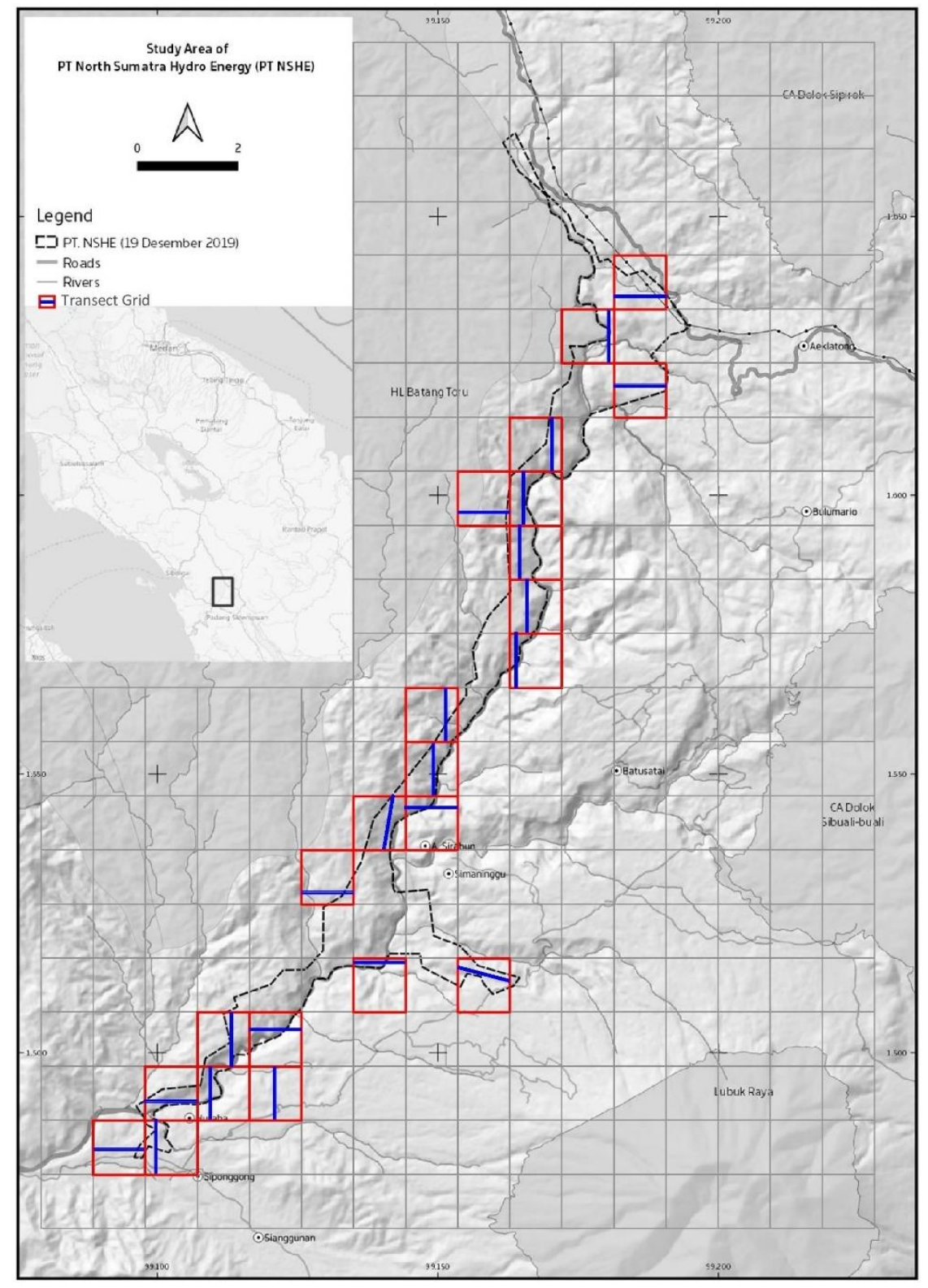

Figure 1. The location of the study area within the total project permits 1,812 hectares and 23 selected grids of the survey transect.

\subsection{Orangutan density}

We conducted a total of $75 \mathrm{~km}$ of line transect length from four different observation time. The first observation was carried out in 2017, the time of the hydropower energy project construction had just started. A total $20 \mathrm{~km}$ transect length was applied and so with the second observation in 2018. The third observation was conducted in 2019 with a total $23 \mathrm{~km}$ transect length, we added more survey transect to cover the riparian area. The final observation was carried out in 2020, the time of project constructions were $90 \%$ completed. The observation was limited to $12 \mathrm{~km}$ total transect length due to project permit changed. As the hydropower energy project was mainly located at the hilly Batang Toru River, we modified the method by applying an occupancy $1 \mathrm{Km}^{2}$ grid to select the targeted area. A random selection within the subset over the study area was applied and observations were focus on 23 grids as the targeted sampling area. Within the chosen grids, we used orangutan nest detection the standard methods that previously was done by researchers (van Schaik et al., 1995; van Schaik et al., 2005; Prasetyo, 2011; Wich \& Boyko, 2011). We calculated the orangutan nest density using the formula that was stated in Equation 1: 


$$
d=\frac{N}{2 . w . L} \quad \text { Equation } 1
$$

where, $d=$ nest density; $N=$ total encountered nest; $w=$ estimated strip width; $L=$ the total length of the transect (Figure 2).

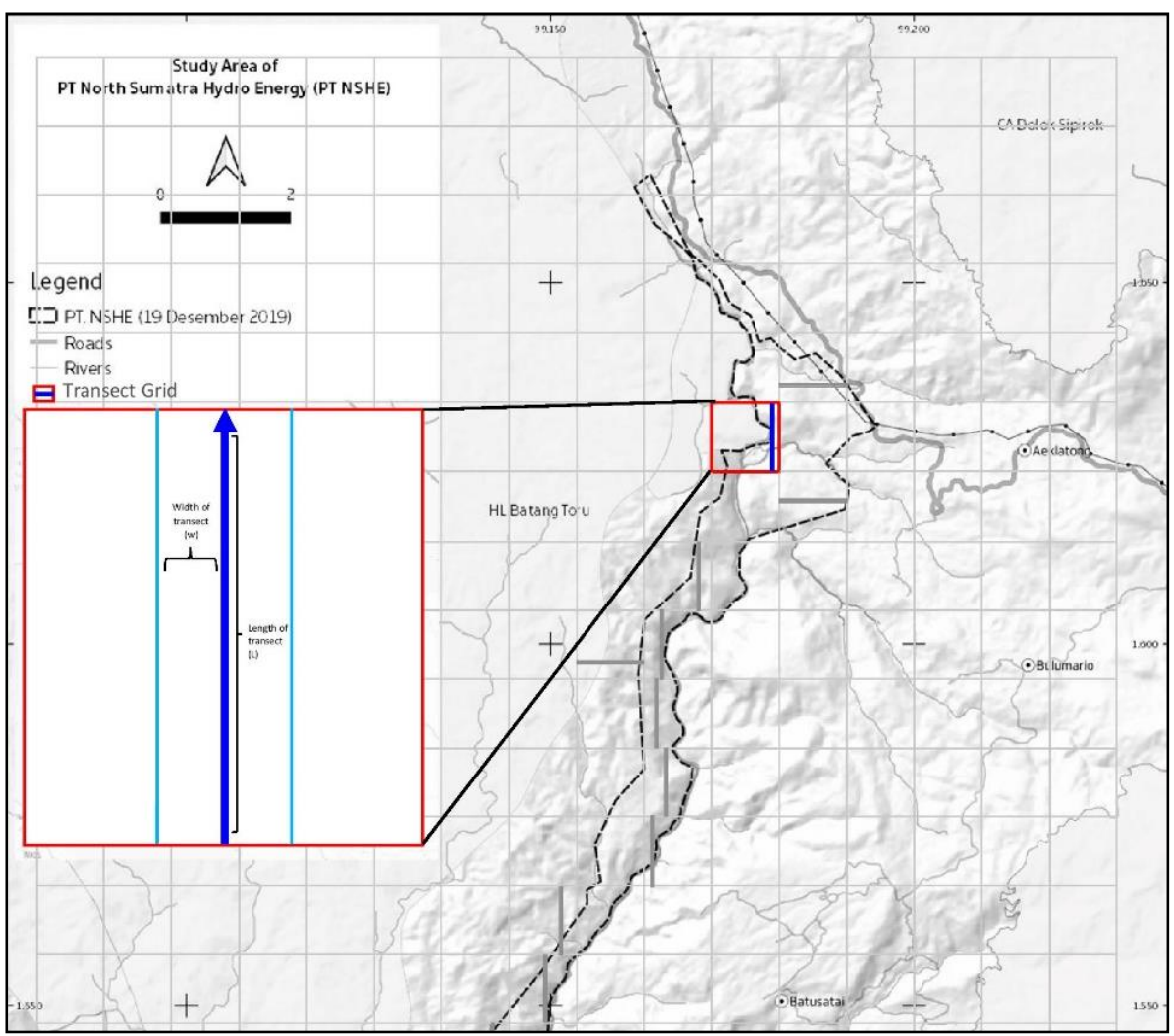

Figure 2. A survey design of line transect placement within the selected grid.

We can convert the nest density into orangutan density by using the formula in Equation 2 (van Schaik et al., 1995; van Schaik et al., 2005):

$$
D=\frac{d}{p . r . t}
$$

Equation 2

where $p$ is the proportion of the population making nests (0.9), $r$ is the rate of nest production (number of nests per capita per day $=1.22$ ), and $t$ is the time of the disappearance of the average nest in days (we were using the $t$ value from the study that was carried out in a similar habitat = 501.5 days (Wich et al., 2016). The calculation was done with DISTANCE 7.3 release 1 (Thomas et al., 2010).

To identify orangutans in the specific area's current existence, the appearance of a new or classified as type A nest could be effectively used (van Schaik et al., 1995). We applied a standard orangutan nest class based on its decay stages. There were (A) fresh, some leaves still green; (B) nest is brown but remains intact; (C) leaves missing and holes appearing in the nest; (D) leaves are gone, the only branch structure of nest remains; and $(E)$ all nest materials were gone (van Schaik et al., 1995).

\subsection{Orangutan habitat suitability}

We used Ecological Niche Modeling with Maximum Entropy (MaxEnt) to evaluate potential habitat for orangutan within the project area, for the occurrence of orangutan nest. MaxEnt showed a useful and effective method to predict habitat suitability and occurrences of this key species (Phillips et al., 2006; Wich et al., 2012). We ran the model by using MaxEnt Software Version 3.4.1., with ten folds, and used cross-validation to evaluate possible errors on the predictive model output. Results from ten independent models were averaged and used as estimates for subsequent 
analyses. To assess model performance from the MaxEnt models, we used the area under the receiver operating characteristic curve (AUC) of the receiver operating characteristic (ROC) plots (Fielding \& Bell, 1997; Cantor et al., 1999). The ROC plot-based approach measures predictive power from predictions (occupied and not occupied) of species distributions (Pearce \& Ferrier, 2000; Liu et al., 2005) and has shown effectiveness in ecological modeling studies (Schadt et al., 2002; Linkie et al., 2004). The resultant AUC values range from 0.5 to 1.0 , where values above 0.7 indicate a precise model fit and above 0.9 indicate a highly accurate model (Swets, 1988).

We collected orangutan nest data ranging from 2017 to 2020 with a total of 236 points. However, we found the point were clustered and mostly concentrated in the areas that we had surveyed more. To reduce spatial auto correlation, we applied a fish-net grid with $3 \mathrm{Km}^{2}$ within the samples and randomly selected one point for each grid. As a result, only 60 points were selected and used to generate a distribution model.

We applied nine environmental spatial variables which likely determined orangutan distribution. These are terrain (elevation, slopes, aspects, terrain ruggedness index), barrier proximity (distance to roads and rivers), climate (annual average temperature and precipitation), and land covers (Table 1). Since there are no latest land cover data for the study area, we conducted a time series land cover analysis using Sentinel 2 Satellite Imagery (ESA 2019) from 2017 as before construction and 2019. We used semi-detailed land cover classification described on High Carbon Stock (HCS) Toolkit Version 2.0 (Rosoman et al., 2017). HCS approach classified land cover into five classes, (1) High-density forest/HDF and (2) Medium density forest/MDF both classes have more than $40 \%$ canopy cover; (3) Low-density forest/LDF with less than $40 \%$ canopy cover; (4) Scrubs/S dominated by more than $80 \%$ canopy cover, and (5) Open Land/OL which contains a non-forest, agricultural areas, settlements, roads, rivers, and open areas (Rosoman et al., 2017). To ensure land cover classification, we conducted a ground accuracy assessment using aerial photos and vegetation surveys on random locations to evaluate performance and refine it. We found accuracy. Both user and producer were $67 \%$ with $\mathrm{K}=0.56$. We prepared all environmental variables at a 10 -meter resolution. Spatial data preparation and analysis was ran by using the Quantum GIS Version 3.10 (Quantum GIS Development Team 2012).

Table 1. The spatial dataset was used to develop the model.

\begin{tabular}{clll}
\hline No. & Dataset & Resolution & Sources \\
\hline 1 & Terrain map & $1: 50.000$ & Geospatial Information Agency \\
\hline 2 & $\begin{array}{l}\text { Sentinel 2 Satellite Imagery, Aug 2017 \& } \\
\text { July 2019 }\end{array}$ & $10 \mathrm{~m}, 60 \mathrm{~m}$ & European Space Agency (ESA) \\
\hline 3 & Digital Elevation Modeling (DEM) Nasional $8 \mathrm{~m}$ & Geospatial Information Agency \\
\hline 4 & Bioclimatic Variables - Downscaled $^{1}$ & $\sim 1 \mathrm{~km}$ & World Climate \\
\hline 5 & Open Street Map & Varied & Open Street Map \\
\hline 6 & Forest cover map 1990 - 2014 & $1: 100.000$ & $\begin{array}{l}\text { Ministry of Environment and } \\
\text { Forestry }\end{array}$ \\
\hline 7 & Construction plan map of PT NSHE & Various & PT NSHE \\
\hline
\end{tabular}

Note: ${ }^{1}$. Downscaled climate data by interpolating climate data using a first-order bilinear spline method with some correction using the Global Summary of the Day database based on various weather stations (collected by the World Meteorological Organization (WMO). For the study, a monthly maximum temperature (Tx), minimum temperature $(\mathrm{Tn})$, average temperature (ta), and precipitation ( $\mathrm{Pr})$ were used which, were collected from five weather stations in North Sumatera Province.

\section{Results}

\subsection{Orangutan Density}

We encountered 236 orangutan nests in $75 \mathrm{~km}$ total length of transects. 74 nests were counted at the beginning of the project constructions around 2017, the next year after we counted 46 nests. In the 2019 observation the number of orangutan nests doubled, and the project construction was about $90 \%$ completed. However, due to the short total length of the transect, we encountered 33 nests in 2020. In 2017, we estimated nest density to be small at the beginning of the project construction, i.e. $49.08 \mathrm{~N} / \mathrm{Km}^{2}$ and then the number increased as most of the activities were 
completed. We assessed the nest density in 2018 to be $52.32 \mathrm{~N} / \mathrm{Km}^{2}$ and increased dramatically in $2019\left(179.62 \mathrm{~N} / \mathrm{Km}^{2}\right)$. However, due to the short observation transect length in 2020, the number of nest densities decreased (Table 2).

Table 2. Distribution of encountered orangutan nest and nest density in different years observation period.

\begin{tabular}{cllll}
\hline No. & Year & $\begin{array}{l}\text { Total length of } \\
\text { transect }(\mathbf{K m})\end{array}$ & $\begin{array}{l}\text { Effective Strip } \\
\text { Width }(\mathbf{m})\end{array}$ & $\begin{array}{l}\boldsymbol{d} \\
\left(\mathbf{N} / \mathbf{K m}^{\mathbf{2}}\right)\end{array}$ \\
\hline 1 & 2017 & 20 & 34.63 & 49.08 \\
\hline 2 & 2018 & 20 & 23.26 & 52.32 \\
\hline 3 & 2019 & 23 & 16.06 & 179.62 \\
\hline 4 & 2020 & 12 & 15.80 & 86.92 \\
\hline
\end{tabular}

The orangutan nest decay stage's distribution showed that classes $C$ and $D$ were dominated in all observation times. Focusing on the new nest's distribution, we observed $9.46 \%$ of class $A$ at the beginning of project construction. At the time of peak disturbance caused by construction activity in 2018, the new orangutan nest was disappearing. However, we observed the appearance of the new nest in 2019 (6.02\%) and 2020 (3.03\%), which indicated that orangutans reappeared (Figure 3).

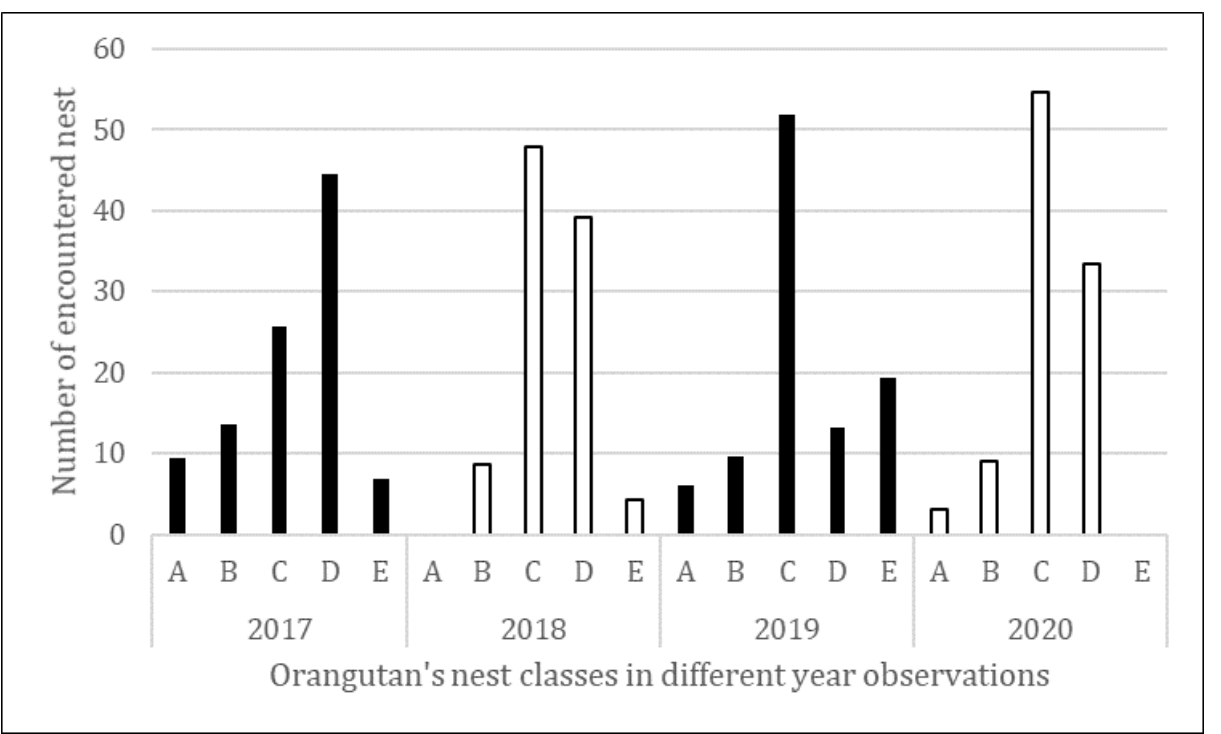

Figure 3. The distribution of orangutan nest decay stage following the five classes system: (a) fresh, some leaves still green; (b) nest is brown but remains intact; (c) leaves missing and holes appearing in nest; (d) leaves are gone, only branch structure of nest remains; and (e) all nest materials were gone.

We estimated orangutan density in 2017 was $0.10 \mathrm{ind} / \mathrm{Km}^{2}(95 \% \mathrm{Cl} 0.06-0.15)$ and slightly decreased in 2018 observation i.e. 0.09 ind $/ \mathrm{Km}^{2}$ (95\% Cl $\left.0.04-0.16\right)$. in 2019. In 2019, we estimated the density to have increased significantly i.e. $0.32 \mathrm{ind} / \mathrm{Km}^{2}(95 \% \mathrm{Cl} 0.19-0.54)$ and at the end of the project construction in 2020, we estimated orangutan density to be 0.16 ind $/ \mathrm{Km}^{2}(95 \% \mathrm{Cl} 0.07$ $-0.35)$.

\subsection{Orangutan Habitat Suitability}

\subsubsection{Land Cover Changed}

Approximately in 2017 , we identified the 1,812 hectares of the study area was dominated by a medium density forest/MDF (783.39 ha), followed by low-density forest/LDF (454.01 ha), highdensity forest/HDF (237.05 ha), young-generated forest/YRF (168.54 ha), cleared area (60.27 ha) and scrubs area (30.36 ha). As seen in Figure 3, the HDF and MDF covered most of the middle project area; meanwhile, the up-downstream areas were covered by scrubs and cleared land in which some vegetation was observed. In 2019, we calculated the medium density forest that was dominated in the study area ( $577.04 \mathrm{ha}$ ) followed by LDF ( $243.85 \mathrm{ha}$ ), scrubs ( $231.75 \mathrm{ha})$, cleared area (233.67 ha), 
YRF (186.89 ha), and HDF (181.37 ha) (Figure 3).

Based on the land cover situation in 2017 and 2019 within the study area, we calculated 484.35 ha of the total area had changed for different purposes. We identified the changes that occurred within the community area (142.58 ha) and company (341.77 Ha). We identified the land cover loss within the study area at the low-density forest ( $210.17 \mathrm{ha}$ ) followed by MDF (206.75 ha), HDF (55.67 ha), and YRF (11.76 ha) (Figure 4).

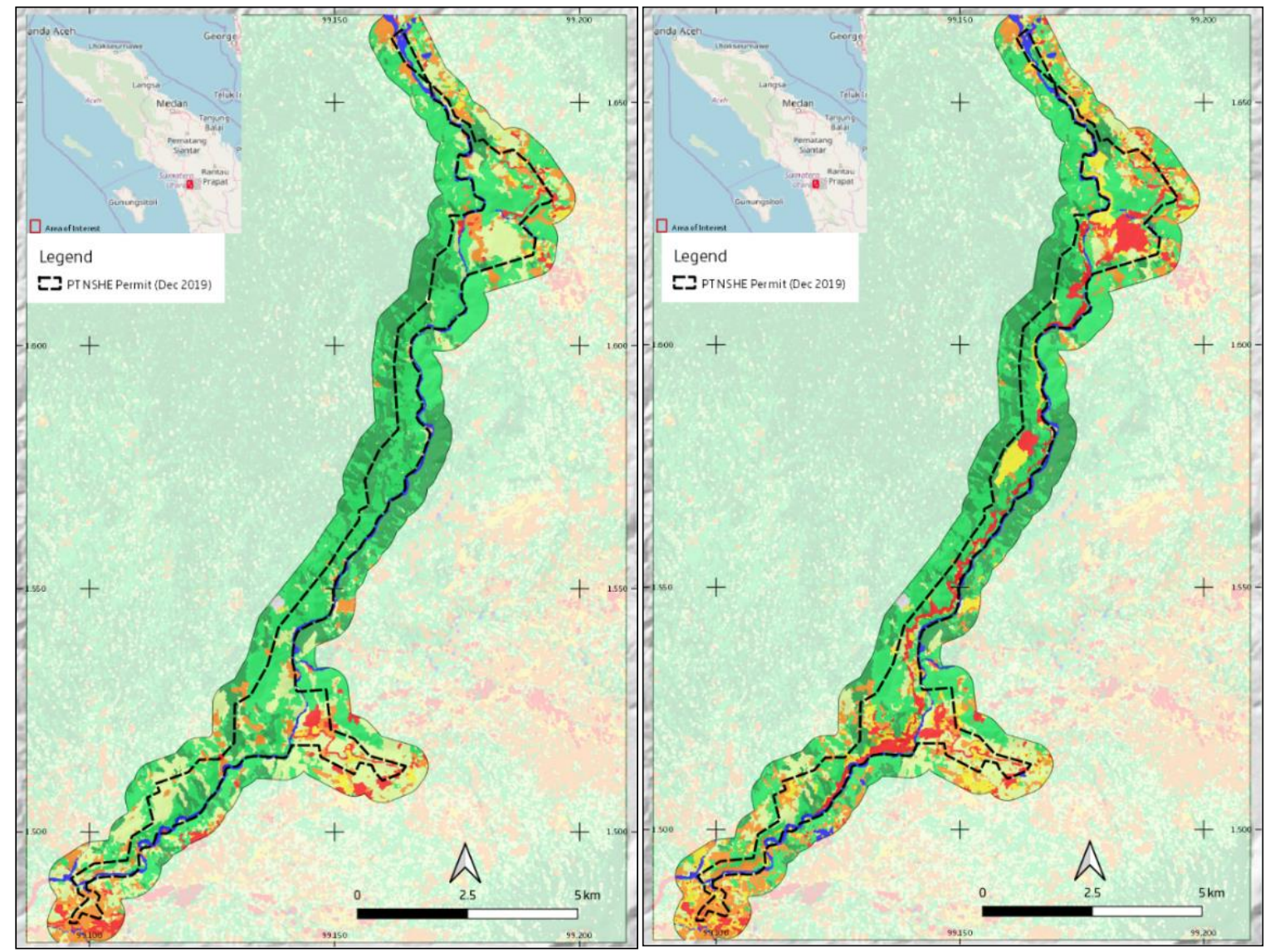

\begin{tabular}{|l|l|l|l|l|}
\hline Land Cover Class & $\mathbf{2 0 1 7}(\mathbf{H a})$ & $\mathbf{2 0 1 9}(\mathbf{H a})$ & Losses $(\mathbf{H a})$ & Gained $(\mathrm{Ha})$ \\
\hline HDF & 237.05 & 181.37 & 55.67 & 474.09 \\
\hline MDF & 783.79 & 577.04 & 206.75 & 1567.59 \\
\hline LDF & 454.01 & 243.85 & 210.17 & 908.03 \\
\hline YRF & 168.54 & 186.89 & 11.76 & -30.11 \\
\hline Scrubs & 30.36 & 231.75 & 0.00 & -201.39 \\
\hline CL & 60.27 & 312.19 & 0.00 & -251.91 \\
\hline Water & 77.36 & 78.08 & 0.00 & -0.72 \\
\hline Others & 0.87 & 1.01 & 0.00 & -0.14 \\
\hline TOTAL & $\mathbf{1 8 1 2 . 2 6}$ & $\mathbf{1 8 1 2 . 1 8}$ & $\mathbf{4 8 4 . 3 5}$ & $\mathbf{- 4 8 4 . 2 7}$ \\
\hline
\end{tabular}

Figure 4. Above: Land-cover situation within the study area in 2017 (left) and 2019 (right). The land cover class was followed by the HCS approach (Rosoman et al., 2017). Below: Total area covered is (ha) based on its land cover classes at the beginning of the project construction in 2017 and at the end of the construction in 2019. The differences in the covered areas were calculated as a loss and a gained.

\subsubsection{Potential Habitat of Orangutan}

We considered the model fit to be excellent as measured by the mean area under the curve (AUC) from the receiver operating characteristics (ROC) which was 0.897 (Hosmer \& Lemeshow, 2000; Phillips et al., 2006). The contextual layer with the highest percentage contribution to the model was roads distribution surrounding the project area (39.9\%), followed by annual precipitation 
$(15.7 \%)$, slopes $(10.2 \%)$, land covers $(9.3 \%)$, the combination between slopes and terrains $(8.8 \%)$, terrain ruggedness index (5.5\%), distance from the rivers (4.3\%), temperature range $(4.2 \%)$, and elevation (2\%). Similarly, the jackknife procedure also indicated road distribution contributed more than any other variables (Figure 5).

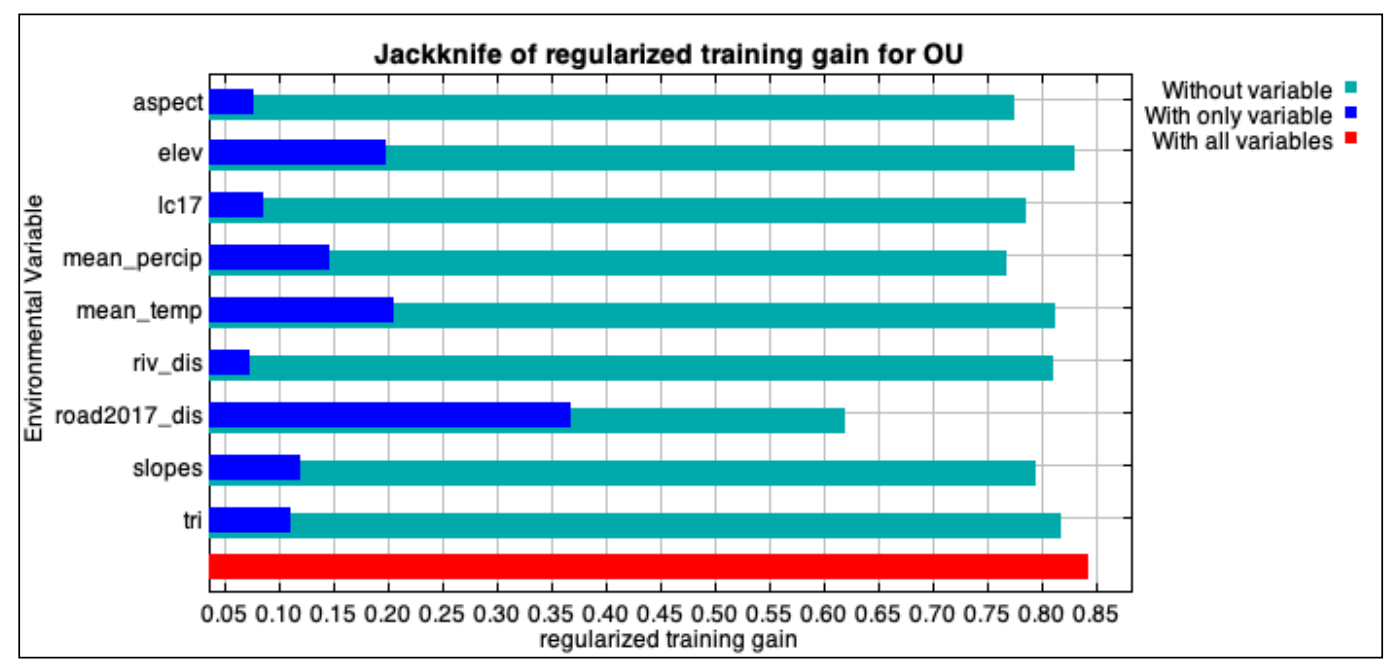

Figure 5. Jackknife procedure from full Maxent model showing the distribution of the road contributed.

We calculated the potential habitat for orangutan in 2017 , it was $1176.25 \mathrm{ha}$, and the remaining area was not suitable for orangutan ( $635.75 \mathrm{ha}$ ). The numbers were changed in 2019; we identified that $20.5 \%$ or 371.68 ha of potential orangutan habitat had changed into project construction purposes. Fortunately, according to the company's plan, the main changes were present for temporary construction purposes (Figure 6, Table 3).

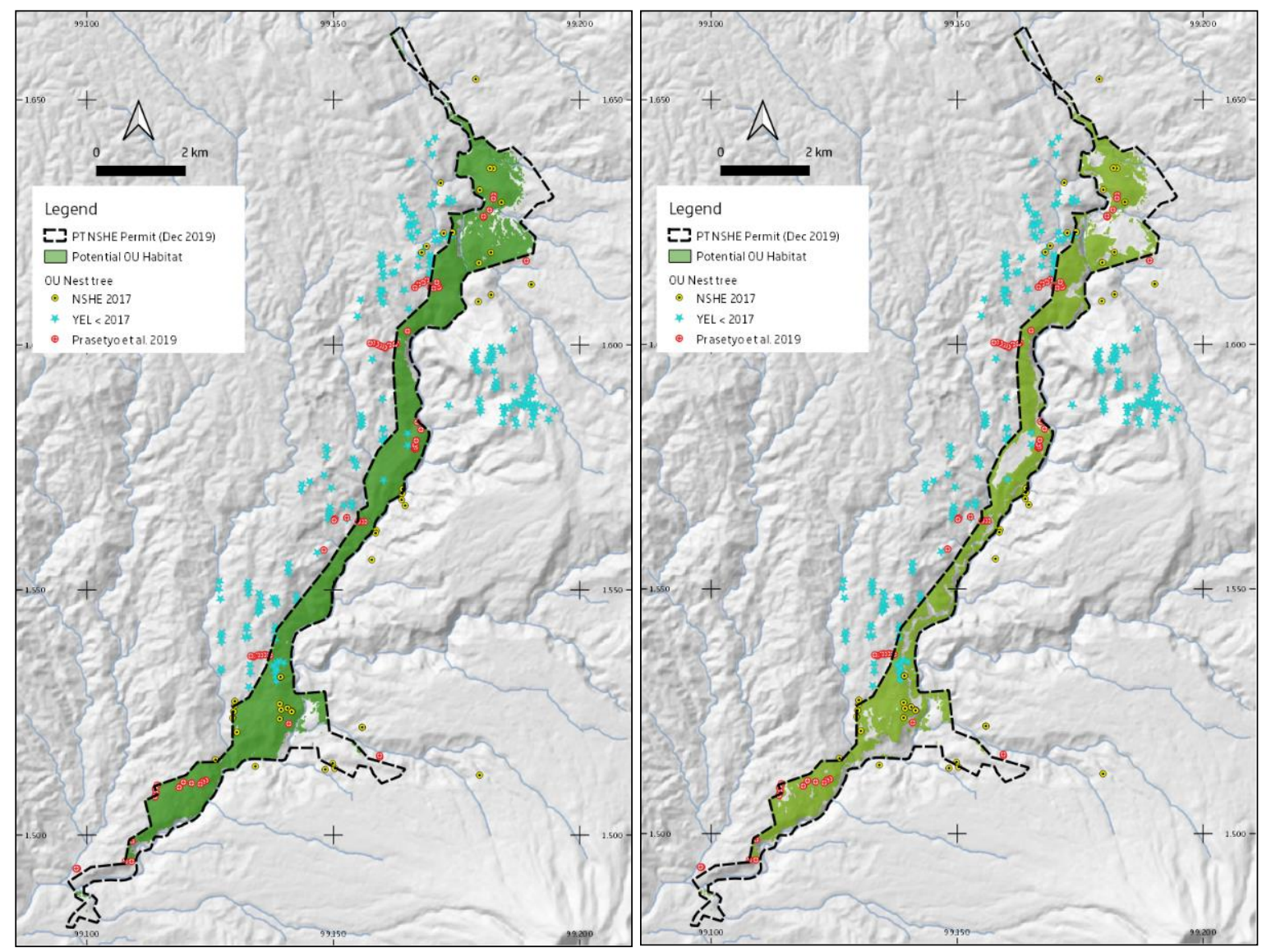

Figure 6. The distribution of potential habitat for orangutan within the study area in 2017 (left) and 2019 (right). Approximately $20.50 \%$ of orangutan habitat was changed for project construction 
purposes.

Table 3. Loss and gain of potential orangutan habitat before and during construction activity within PT NSHE.

\begin{tabular}{|l|l|l|l|l|l|}
\hline \multirow{2}{*}{ Construction Type } & \multicolumn{2}{|l|}{ No Suitable (Ha) } & \multicolumn{2}{l|}{ Suitable (Ha) } & Loss and gained \\
\cline { 2 - 6 } & $\mathbf{2 0 1 7}$ & $\mathbf{2 0 1 9}$ & $\mathbf{2 0 1 7}$ & $\mathbf{2 0 1 9}$ & $\mathbf{( H a )}$ \\
\hline Permanent & 74.09 & 160.55 & 125.99 & 39.52 & 86.47 \\
\hline Temporary & 561.66 & 846.87 & 1050.26 & 765.06 & 285.21 \\
\hline Grand Total & 635.75 & 1007.43 & 1176.25 & 804.57 & 371.68 \\
\hline
\end{tabular}

\section{Discussion}

This study provides the first quantitative estimation of Tapanuli orangutan density's status following the project construction time frames of the hydro-energy dam project, from the start to the end of construction activities. The study was covered $2 \%$ from the previous study that was conducted within Batang Toru ecosystem (Sloan et al., 2018; Wich et al., 2019). We encountered the orangutan density at the beginning of the project constructions was 0.09 ind $/ \mathrm{Km}^{2}$, a similar number was found in the peak time of construction activities in 2018. Moreover, we found the population density significantly increased when the construction activities were limited, which led to more significantly less disturbance. Although the trend of orangutan density from the final observation of this study was different, a small total transect length generated the reduction. Based on the findings, we observed high disturbance affect the orangutan appearances, orangutans would avoid the disturbed area and maybe reappeared if the food is abundant. We assume that orangutans would temporarily disappear and return as the area is safe. Some cases reported that orangutans density within the disturbed forest remain similar with unlogged forest (Knop et al., 2004). Though they can survive in highly disturbed forest (Meijaard et al., 2010) by adjusting their behavior (Hardus et al., 2012) and applying the energy intake strategy (Knott, 1998; Vogel et al., 2009; Vogel et al., 2012).

Previously, several surveys have been done in the bigger area i.e.: Batang Toru ecosystem as well as within the hydropower dam project. The study from the Batang Toru ecosystem reported the orangutan density was 0.23 ind $/ \mathrm{Km}^{2}$ (Wich et al., 2012). The estimation was based on analysis within $973 \mathrm{Km}^{2}$ study area in which the orangutan's abundance was mainly found in the west block i.e. 151 orangutans (95\% Cl 94-231, $388 \mathrm{Km}^{2}$ coverage area) and 74 orangutans in the east block (95\% Cl 45-112, $585 \mathrm{Km}^{2}$ coverage area) (Wich et al., 2012). Specifically, Nasution et al. (2018) conducted a study in the east block and focused on the Sibual-buali reserve area in 2015 and estimated the population density to be $0.4 \mathrm{ind} / \mathrm{Km}^{2}$. Recently, Nasution et al. (2020) published a new update on Tapanuli orangutan density focusing on east block population. They found the ranges to be from $0.14-0.74 \mathrm{ind} / \mathrm{Km}^{2}$ depending on geographical elevation and land status. The studies within hydro-energy dam project were previously done by Kuswanda and Noor CH (2017) which found orangutan density within the project area was $0.41 \mathrm{ind} / \mathrm{Km}^{2}$. A year later, they revisited the study and estimated the orangutan density tend to be decreased to $0.35 \mathrm{ind} / \mathrm{Km}^{2}$ (Balitbang-LHKAek-Nauli \& BBKSDA-Sumatera-Utara, 2018). However, those studies were used a different method which led to a different result from previous orangutan density study for Tapanuli orangutan. Our finding supports previous study in which orangutan density was increased at the time of less disturbances from the construction activities considering low threats (Wich et al., 2012; Nasution et al., 2020).

The distribution of Tapanuli orangutan was focused in undisturbed forest (Wich et al., 2012), and other populations could be found in the disturbed forest (Nasution et al., 2020; Kuswanda et al., 2020). Aligned with those findings, Rahman et al. (2019) calculated the suitability habitat for Tapanuli orangutan, which protected area was potentially suitable for orangutans i.e. $1.070,90 \mathrm{Km}^{2}$ and some potential habitat could be found in the non-protected area $\left(387,16 \mathrm{Km}^{2}\right)$. Our study found a similar observation, about $90 \%$ of the company area was suitable for the orangutan. The orangutans preferred to live in the medium forest density which provided more food resources. Based on 342 tree species that were identified, 41\% were known as orangutan food trees e.g. 
Pometiasp., Syzygium sp., Ficus sp., and Artocarpus sp. Most of Ficus sp was known to be an important orangutan's food resource and abundant in the Batang Toru forest (Pasaribu et al., 2018).

\subsection{Management Implications}

None of the natural resource concessions, small or large scales and whatever was purposed could not avoid the forest disturbance. As economic development is prioritized by various countries, environmentalist through individual and institutions are conducting research and guided on how to reduce the impact from its practice especially relating to the use of natural resources. Scientists concerned with the protection of the newly described orangutan species proposed several conservation steps, P. tapanuliensis (Nater et al., 2017; Wich et al., 2019). That is because this species has only a few population numbers compared to the two other orangutan species, i.e. Pongo abelii and Pongo pygmaeus (Wich et al., 2008), living in the patchy forest blocks i.e. west and east blocks, and facing high threats from insecure forest status, encroachment, hunting, and concession activities (Utami-Atmoko et al., 2017; Wich et al., 2019). Moreover, the main threat to the Batangtoru ecosystem was mostly as a result of agriculture expansion. In the new orangutan action plan 2019-2029, scientists projected $1.2 \%$ of Tapanuli orangutan would be lost in the next decade (Utami-Atmoko et al., 2019).

The relationship between wildlife species and their habitats has been a central issue in conservation biology studies as one of the information inputs for conservation planning. Identifying key habitat variables with their spatial arrangement to which a species responds and habitat modeling to predict species occupancy is vital to develop conservation management plans for species (MacKenzie et al., 2006) and landscape conservation planning (Sanderson et al., 2002). Many ecological studies have been done using species occurrences to model habitat relationships (Wilting et al., 2011; Sunarto et al., 2012). To develop this relationship, a comprehensive dataset is required; however, common issues are the problem of inadequate resources, funding, and workforce. As a result, many baselines ecological datasets of species are poorly known, or even no information that can mislead the management of the species. Several developments in ecological niche modeling (ENM) have provided a new tool that can cautiously estimate species ranges and identify suitable habitats. We observed our model with MaxEnt framework (Phillips et al., 2006) appears to provide a useful model to evaluate the impact of the project development on the orangutans' habitat, which can be used also to mitigate the future impact. However, we encourage this model not as an exhaustive tool to investigate a dynamic impact, such as wildlife and habitat interactions.

Our study concludes the project constructions may cause a high disturbance impact for orangutans and maybe other wildlife, as shown their density which was very low at the beginning of the construction activities. After the construction was completed, the orangutan's density opens some possibility to reverse. The project construction was changed to about 372 ha of the area suitable for orangutans for permanent constructions ( $87 \mathrm{ha}$ ) and temporary construction purposes (285 ha). As the population's rebound was showing within the natural forest concessions (Meijaard et al., 2005; Prasetyo, 2011), our study proposes several steps to mitigate the project impact on the orangutans (and other wildlife) populations, there are:

\subsubsection{Orangutans' corridor}

As the distribution of Tapanuli orangutan was separated into two different and more significant populations i.e. west and east blocks (Wich et al., 2019), and the population within the east block was scattered into some small populations (Nasution et al., 2020; Kuswanda et al., 2020). The local government has initiated the creation of corridors to connect the orangutan populations known as Sibual-buali corridor and Sipirok corridor to connect the west and east population, and a corridor to connect Sibual-buali and Sipirok populations. As the area study was located at the edge of west block populations, we proposed three important areas that could be connected to the planned government's corridors i.e. the upstream area that is located at the dam site, the middle area located at the spoil-bank 5, and the downstream which is concentrated at the power-house area (Figure 7).

Moreover, we identified that the private access road had cleared forest and covers an approximate caused degraded forest of about $15 \mathrm{~m}-40 \mathrm{~m}$ wide at a particular point along the corridor over a distance of approximately $17 \mathrm{Km}$ parallel to and on the West side of the Batang Toru 
River. We proposed the project to achieve the sufficient width of their private road to 6 meter following construction regulation and aggressively reforested all other areas subject to temporary clearing for construction. As concerned by some enthusiastic scientist regarding the study area might separate the orangutans' populations (Sloan et al., 2018; Sloan et al., 2019; Wich et al., 2019), orangutan movement across the access road could be realized by creating an artificial bridge within the area that have high orangutan density or appearances. Although, there is no scientific evidence on Tapanuli orangutan could pass the road, and artificial bridge, a shred of evidence had been reported for Bornean orangutan, which is adaptable to cross the forest patches by using artificial corridor (Ancrenaz, 2010). Moreover, exhaustive surveys of the Toru river's entire length also revealed the existence of one or two natural arboreal crossings over the Batang Toru river through the project area. Those potential natural corridors shall be protected, and an artificial corridor could be added to facilitate orangutans' movement, specifically among the small forest patches (Ancrenaz et al., 2021).

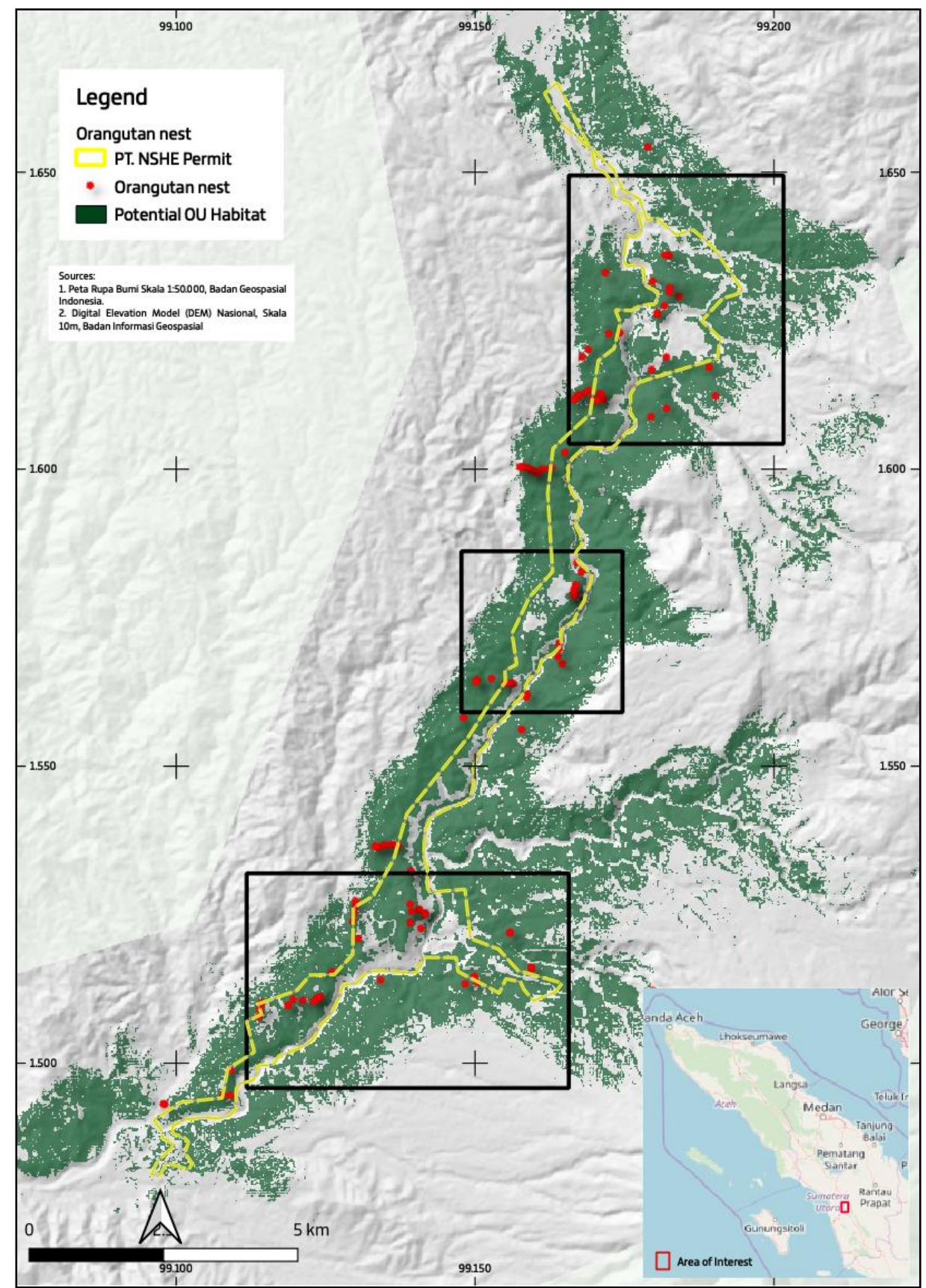

Figure 7. Three proposed areas for orangutans' connectivity within the study area. 


\subsubsection{Minimize human activities within the vital habitat for orangutans.}

It was analyzed that one of the causes of the declining orangutans' population is hunting (Meijaard et al., 2011; Meijaard et al., 2012; Davis et al., 2013; Abram et al., 2015; Voigt et al., 2018; Meijaard et al., 2021). Moreover, Wich et al. (2012) observed that hunting for Sumatran orangutan often occurred within lower geographical elevation. As the study area's road development area might initiate the people access that might be related to the hunting activity, forbidden access for the non-related project shall be regulated. Also, shifting and minimizing access to the important habitat for orangutans shall be applied for all related project activities.

\subsubsection{Restoration and offset for affected orangutan habitat.}

As calculated, 371.68 ha of potential habitat for orangutan have been converted into project purposes, 86.47 ha for permanent constructions and 285.21 ha was for temporary project needs and impacted areas. Restoration shall be focused on the area not for permanent purposes and prioritize the orangutans' need. From 2472 trees, we identified 342 species in which orangutans' food resources used 139 tree species. Furthermore, we listed the ten most common orangutans' food resources that might be prioritized as species for restoration activity, although the fast-growing species is preferred (Table 4).

Table 4. Most common orangutans' food tree species within the study area.

\begin{tabular}{|c|c|c|c|c|c|c|}
\hline No. & Genus/species & Density/Ha & $\begin{array}{c}\text { Dominance } \\
\text { Relative }\end{array}$ & $\begin{array}{l}\text { Density } \\
\text { Relative }\end{array}$ & $\begin{array}{c}\text { Frequency } \\
\text { relative }\end{array}$ & IVI \\
\hline 1 & Pometia pinnata & 0.71 & 10.73 & 1.42 & 0.73 & $\begin{array}{c}12.8 \\
7\end{array}$ \\
\hline 2 & Syzygium sp. & 0.16 & 2.35 & 1.94 & 1.04 & 5.33 \\
\hline 3 & Ficus $s p$ & 0.17 & 2.54 & 1.21 & 1.04 & 4.79 \\
\hline 4 & Duriozibethinus & 0.23 & 3.51 & 0.40 & 0.62 & 4.53 \\
\hline 5 & $\begin{array}{l}\text { Artocarpus } \\
\text { elasticus }\end{array}$ & 0.18 & 2.76 & 0.65 & 0.94 & 4.34 \\
\hline 6 & Artocarpus sp. & 0.10 & 1.54 & 1.33 & 1.04 & 3.92 \\
\hline 7 & $\begin{array}{l}\text { Artocarpus } \\
\text { lanceifolius }\end{array}$ & 0.15 & 2.22 & 0.93 & 0.73 & 3.88 \\
\hline 8 & Dysoxylum sp. & 0.07 & 1.00 & 1.54 & 0.94 & 3.47 \\
\hline 9 & Palaquium sp. & 0.08 & 1.21 & 0.97 & 0.94 & 3.12 \\
\hline 10 & Santiria sp. & 0.09 & 1.32 & 0.81 & 0.73 & 2.86 \\
\hline
\end{tabular}

For the non-restored area, orangutans' habitat offset could be implemented within the area that was identified as crucial for the corridor. Although, the implementation might be challenged, the collaboration could be conducted with local communities and government. The previous findings on orangutan distribution outside the protected area shall be considered (Nasution et al., 2020; Kuswanda et al., 2020).

\section{Conclusions}

Our study concluded the orangutans' appearances were potentially returning as the disturbance is reduced and the habitat restored along with other potential threats such as human access was restricted. The population density could be a rebound by applying a precautionary management plan for orangutans and other species i.e.: creating corridor(s) to facilitate orangutans' movement, minimize the access for human activities, and restore the impacted areas. In collaboration with the advanced technology and knowledge, the project impact could be possible minimized as demonstrated by some other concession's types. Finally, future study on the habitat utilization by orangutan could be conducted to monitor the its adaptation within and surrounding the dam project area, specifically in the use of corridor(s) and restored habitat area.

Author Contributions: D.P., Y.H., and W.K. designed and performed the field assessment; D.P. and Y.H. performed the data analysis. D.P., Y.H., W.K., and J.S. wrote the paper. 
Conflicts of Interest: The authors declare no conflict of interest.

Acknowledgments: We thank the Ministry of Forestry and Environmental of Indonesia, specifically Balai Besar Konservasi Daya Alam Sumatera Utara and Balai Penelitian Kehutanan Aek Nauli , who assisted and facilitated this study. We are grateful to the South Tapanuli government, who gave permission and the Center for Sustainable Environmental and Resources Management (CSERM) Universitas Nasional who funded this study. We are grateful to the local community who gave a great discussion such as LSLI, OPMU, PERHAPPI. Finally, we thank the North Sumatera Hydro Energy who allowed the study within their project area.

\section{References}

Abram, N. K., Meijaard, E., Wells, J. A., Ancrenaz, M., Pellier, A.-S., Runting, R. K., . . Richardson, D. (2015). Mapping perceptions of species' threats and population trends to inform conservation efforts: the Bornean orangutan case study. Diversity and Distributions, 21(5), 487-499. https://doi.org/10.1111/ddi.12286

Ancrenaz, M. (2010). Orang-utan bridges in lower Kinabatangan. Retrieved from https://www.arcusfoundation.org/wp-content/uploads/2010/01/Kinabatangan-

Orangutan-Rope-Bridges-Ancrenaz-2010.pdf

Ancrenaz, M., Oram, F., Nardiyono, N., Silmi, M., Jopony, M. E. M., Voigt, M., . . Meijaard, E. (2021). Importance of Small Forest Fragments in Agricultural Landscapes for Maintaining Orangutan Metapopulations. Frontiers in Forests and Global Change, 4, 560944, 1-7. https://doi.org/10.3389/ffgc.2021.560944

Balitbang-LHK-Aek-Nauli, \& BBKSDA-Sumatera-Utara. (2018). Laporan Kegiatan Analisis Populasi Orangutan dan Satwa Langka Lainnya Pada Musim Kering di Wilayah Kerja PT. NSHE, Tapanuli Selatan. BP2LHK Aek Nauli dan BBKSDA Sumatera Utara.

Cantor, S. B., Sun, C. C., Tortolero-Luna, G., Richards-Kortum, R., \& Follen, M. (1999). A comparison of $C / B$ ratios from studies using receiver operating characteristic curve analysis. Journal of clinical epidemiology, 52(9), 885-892. https://doi.org/10.1016/S0895-4356(99)00075-X

Davis, J. T., Mengersen, K., Abram, N. K., Ancrenaz, M., Wells, J. A., \& Meijaard, E. (2013). It's not just conflict that motivates killing of orangutans. PloS one, 8(10), e75373. https://doi.org/10.1371/journal.pone.0075373

Fielding, A. H., \& Bell, J. F. (1997). A review of methods for the assessment of prediction errors in conservation presence/absence models. Environmental Conservation, 24(1), 38-49. https://doi.org/10.1017/S0376892997000088

Hardus, M. E., Lameira, A. R., Menken, S. B. J., \& Wich, S. A. (2012). Effects of logging on orangutan behavior. Biological Conservation, 146(1),

https://doi.org/10.1016/j.biocon.2011.12.014

Hosmer, D. W., \& Lemeshow, S. (2000). Applied Logistic Regression (2 ed.). John Wiley \& Sons. https://doi.org/10.1002/0471722146

Knop, E., Ward, P. I., \& Wich, S. A. (2004). A comparison of orang-utan density in a logged and unlogged forest on Sumatra. Biological Conservation, 120(2), 183-188. https://doi.org/10.1016/j.biocon.2004.02.010

Knott, C. D. (1998). Changes in orangutan caloric intake, energy balance, and ketones in response to fluctuating fruit availability. International Journal of Primatology, 19(6), 1061-1079. https://doi.org/10.1023/A:1020330404983

Kuswanda, W., Harahap, R. H., Alikodra, H. S., \& Sibarani, R. (2020). Nest characteristics and populations of Tapanuli Orangutans in the conflict areas, Batangtoru Landscape, North Sumatra, Indonesia. Biodiversitas Journal of Biological Diversity, 21(7), 3398-3406. https://doi.org/10.13057/biodiv/d210765

Kuswanda, W., \& Noor CH, F. (2017). Laporan Hasil Survai: Analisis Populasi Orangutan dan Satwa Lainnya pada Wilayah Kerja PT. NSHE di Batang Toru.

Linkie, M., Smith, R. J., \& Leader-Williams, N. (2004). Mapping and predicting deforestation patterns in the lowlands of Sumatra. Biodiversity \& Conservation, 13(10), 1809-1818. https://doi.org/10.1023/B:BIOC.0000035867.90891.ea

Liu, C., Berry, P. M., Dawson, T. P., \& Pearson, R. G. (2005). Selecting thresholds of occurrence in the 
prediction of species distributions.

Ecography, 28(3),

385-393.

https://doi.org/10.1111/j.0906-7590.2005.03957.x

MacKenzie, D. I., Nichols, J. D., Royle, J. A., Pollock, K. H., Bailey, L. L., \& Hines, J. E. (2006). Occupancy Estimation and Modeling: Inferring Patterns and Dynamics of Species Occurrence. Elsevier/Academic Press.

Meijaard, E., Albar, G., Nardiyono, Rayadin, Y., Ancrenaz, M., \& Spehar, S. (2010). Unexpected Ecological Resilience in Bornean Orangutans and Implications for Pulp and Paper Plantation Management. PLoS One, 5(9), e12813. https://doi.org/10.1371/journal.pone.0012813\

Meijaard, E., Buchori, D., Hadiprakarsa, Y., Utami-Atmoko, S. S., Nurcahyo, A., Tjiu, A., \& Prasetyo, D. (2012). Correction: Quantifying Killing of Orangutans and Human-Orangutan Conflict in Kalimantan, Indonesia. PLoS One, 7(3). https://doi.org/10.1371/annotation/7b65cf64-9fd54b95-baf2-8824c4785ab1

Meijaard, E., Buchori, D., Hadiprakarsa, Y., Utami-Atmoko, S. S., Nurcahyo, A., Tjiu, A., . . . Mengersen, K. (2011). Quantifying killing of orangutans and human-orangutan conflict in Kalimantan, Indonesia. PLoS One, 6(11), e27491. https://doi.org/10.1371/journal.pone.0027491

Meijaard, E., Ni'matullah, S., Dennis, R., Sherman, J., Onrizal, \& Wich, S. A. (2021). The historical range and drivers of decline of the Tapanuli orangutan. PLoS One, 16(1), e0238087. https://doi.org/10.1371/journal.pone.0238087

Meijaard, E., Sheil, D., Nasi, R., Augeri, D., Rosenbaum, B., Iskandar, D., ... O’Brien, T. (2005). Life after logging: Reconciling wildlife conservation and production forestry in Indonesian Borneo. CIFOR. https://doi.org/10.17528/cifor/001663

Nasution, A., Perwitasari-Farajallah, D. Y. A. H., \& Utami-Atmoko, S. S. (2020). The distribution and density of Tapanuli orangutans (Pongo tapanuliensis) at potential corridor locations between forest fragments in Batang Toru, North Sumatra, Indonesia. Biodiversitas Journal of Biological Diversity, 21(11), 5382-5388. https://doi.org/10.13057/biodiv/d211144

Nasution, A., Perwitasari-Farajallah, D., \& Utami Atmoko, S. S. (2018). Declining orangutans population in the unprotected forest of Batang Toru. Tropical Life Sciences Research, 29(2), 77-87. https://dx.doi.org/10.21315\%2Ftlsr2018.29.2.6

Nater, A., Mattle-Greminger, M. P., Nurcahyo, A., Nowak, M. G., de Manuel, M., Desai, T., . . . Krutzen, M. (2017). Morphometric, Behavioral, and Genomic Evidence for a New Orangutan Species. Current Biology, 27(22), 3487-3498. https://doi.org/10.1016/j.cub.2017.09.047

Nowak, M. G., Rianti, P., Wich, S. A., Meijaard, E., \& Fredriksson, G. (2017). Pongo tapanuliensis. The IUCN Red List of Threatened Species 2017. https://dx.doi.org/10.2305/IUCN.UK.20173.RLTS.T120588639A120588662.en

Pasaribu, N., Aththorick, T. A., \& Siswiyati, E. (2018). Study of Ficus in West Block Batang Toru Forest Region, North Tapanuli District, Indonesia. Journal of Physics: Conference Series, 1116(5), 16. https://doi.org/10.1088/1742-6596/1116/5/052049

Pearce, J., \& Ferrier, S. (2000). Evaluating the predictive performance of habitat models developed using logistic regression. Ecological Modelling, 133(3), 225-245. https://doi.org/10.1016/S0304-3800(00)00322-7

Phillips, S. J., Anderson, R. P., \& Schapire, R. E. (2006). Maximum entropy modeling of species geographic distributions. Ecological Modelling, 190(3-4), 231-259. https://doi.org/10.1016/j.ecolmodel.2005.03.026

Prasetyo, D. (2011). Nest density as determinants for habitat utilizations of Bornean orangutan (Pongo pygmaeus wurmbii) in degraded forests of Gunung Palung National Park, West Kalimantan. Biodiversitas, Journal of Biological Diversity, 12(1), 164-170. https://doi.org/10.13057/biodiv/d120306

Prasetyo, D., Misdi, M., Mulyana, T., Cholifatullah, F., Sadjudin, H., Kuswanda, W., \& Sugardjito, J. (2021). Preliminary survey of the southernmost Tapanuli orangutan population. Oryx, 55(4), 495-495. https://doi.org/10.1017/\$0030605321000491

Rahman, D. A., Rinaldi, D., Kuswanda, W., Siregar, R., Noor CH, F., Hakim, F., . . Putro, H. R. (2019). Determining the landscape priority and their threats for the critically endangered Pongo tapanuliensis population in Indonesia. Biodiversitas Journal of Biological Diversity, 20(12), 
3584-3592. https://doi.org/10.13057/biodiv/d201217

Rosoman, G., Sheun, S. S., Opal, C., Anderson, P., \& Trapshah, R. (2017). The HCS Approach Toolkit. HCS Approach Steering Group.

Sanderson, E. W., Redford, K. H., Vedder, A., Coppolillo, P. B., \& Ward, S. E. (2002). A conceptual model for conservation planning based on landscape species requirements. Landscape and Urban Planning, 58(1), 41-56. https://doi.org/10.1016/S0169-2046(01)00231-6

Schadt, S., Knauer, F., Kaczensky, P., Revilla, E., Wiegand, T., \& Trepl, L. (2002). Rule-based assessment of suitable habitat and patch connectivity for the eurasian lynx. Ecological Applications, 12(5), 1469-1483. https://doi.org/10.1890/10510761(2002)012[1469:RBAOSH]2.0.CO;2

Sloan, S., Alamgir, M., Campbell, M. J., Setyawati, T., \& Laurance, W. F. (2019). Development Corridors and Remnant-Forest Conservation in Sumatra, Indonesia. Tropical Conservation Science, 12, 1-9. https://doi.org/10.1177\%2F1940082919889509

Sloan, S., Supriatna, J., Campbell, M. J., Alamgir, M., \& Laurance, W. F. (2018). Newly discovered orangutan species requires urgent habitat protection. Current Biology, 28(11), R650-R651. https://doi.org/10.1016/j.cub.2018.04.082

Sunarto, S., Kelly, M. J., Parakkasi, K., Klenzendorf, S., Septayuda, E., \& Kurniawan, H. (2012). Tigers need cover: multi-scale occupancy study of the big cat in Sumatran forest and plantation landscapes. PLoS One, 7(1), e30859. https://doi.org/10.1371/journal.pone.0030859

Swets, J. A. (1988). Measuring the Accuracy of Diagnostic Systems. Science, 240(4857), 1285-1293. https://doi.org/10.1126/science.3287615

Thomas, L., Buckland, S. T., Rexstad, E. A., Laake, J. L., Strindberg, S., Hedley, S. L., . . Burnham, K. P. (2010). Distance software: design and analysis of distance sampling surveys for estimating population size. Journal of Applied Ecology, 47(1), 5-14. https://doi.org/10.1111/j.13652664.2009.01737.x

Utami-Atmoko, S., Traylor-Holzer, K., Rifqi, M. A., Siregar, P. G., Achmad, B., Priadjati, A., . . Lees, C. M. (2019). [Unpublished] Orangutan Population and Habitat Viability Assessment: Final Report. Retrieved from www.cpsg.org and www.forina.or.id

Utami-Atmoko, S. S., Traylor-Holzer, K., Rifqi, M. A., Siregar, P. G., Achmad, B., Priadjati, A., ... Lees, C. M. (2017). Orangutan Population and Habitat Viability Assessment: Final Report. Retrieved from www.cpsg.org and www.forina.or.id

van Schaik, C. P., Azwar., \& Priatna, D. (1995). Population Estimates and Habitat Preferences of Orangutans Based on Line Transects of Nests. In Nadler R.D., Galdikas B.F.M., Sheeran L.K., Rosen N. (eds) The Neglected Ape. Springer. https://doi.org/10.1007/978-1-4899-10912_15

van Schaik, C. P., Wich, S. A., Utami, S. S., \& Odom, K. (2005). A simple alternative to line transects of nests for estimating orangutan densities. Primates, 46(4), 249-254. https://doi.org/10.1007/s10329-005-0134-z

Vogel, E. R., Haag, L., Mitra-Setia, T., van Schaik, C. P., \& Dominy, N. J. (2009). Foraging and ranging behavior during a fallback episode: Hylobates albibarbis and Pongo pygmaeus wurmbii compared. American Journal of Physical Anthropology: The Official Publication of the American Association of Physical Anthropologists, 140(4), 716-726. https://doi.org/10.1002/ajpa.21119

Vogel, E. R., Knott, C. D., Crowley, B. E., Blakely, M. D., Larsen, M. D., \& Dominy, N. J. (2012). Bornean orangutans on the brink of protein bankruptcy. Biology Letter, 8(3), 333-336. https://dx.doi.org/10.1098\%2Frsbl.2011.1040

Voigt, M., Wich, S. A., Ancrenaz, M., Meijaard, E., Abram, N., Banes, G. L., . . Kuhl, H. S. (2018). Global Demand for Natural Resources Eliminated More Than 100,000 Bornean Orangutans. Current Biology, 28(5), 761-769. https://doi.org/10.1016/j.cub.2018.01.053

Wich, S. A., \& Boyko, R. H. (2011). Which factors determine orangutan nests' detection probability along transects? Tropical Conservation Science, 4(1), 53-63. https://doi.org/10.1177\%2F194008291100400106

Wich, S. A., Fredriksson, G., Usher, G., Kuhl, H. S., \& Nowak, M. G. (2019). The Tapanuli orangutan: Status, threats, and steps for improved conservation. Conservation Science and Practice, 
1(6), 1-4. https://doi.org/10.1111/csp2.33

Wich, S. A., Fredriksson, G. M., Usher, G., Peters, H. H., Priatna, D., Basalamah, F., . . Kühl, H. (2012). Hunting of Sumatran orang-utans and its importance in determining distribution and density Biological Conservation, 146(1), 163-169. https://doi.org/10.1016/j.biocon.2011.12.006

Wich, S. A., Meijaard, E., Marshall, A. J., Husson, S., Ancrenaz, M., Lacy, R. C., . . Singleton, I. (2008). Distribution and conservation status of the orang-utan (Pongo spp.) on Borneo and Sumatra: how many remain? Oryx, 43(3), 329-339. https://doi.org/10.1017/S003060530800197X

Wich, S. A., Singleton, I., Nowak, M. G., Utami-Atmoko, S. S., Nisam, G., Arif, S. H., . . Kühl, H. S. (2016). Land-cover changes predict steep declines for the Sumatran orangutan (Pongo abelii). Science Advances, 2(3), 1-8. https://dx.doi.org/10.1126\%2Fsciadv.1500789

Wilting, A., Christiansen, P., Kitchener, A. C., Kemp, Y. J., Ambu, L., \& Fickel, J. (2011). Geographical variation in and evolutionary history of the Sunda clouded leopard (Neofelis diardi) (Mammalia: Carnivora: Felidae) with the description of a new subspecies from Borneo. Molecular Phylogenetics and Evolution, 58(2), 317-328. https://doi.org/10.1016/j.ympev.2010.11.007 